\title{
Jak zmierzyć demokrację? Teoretyczne i metodologiczne podstawy budowy skal demokracji politycznej w politologii porównawczej
}

\begin{abstract}
Wstęp
Dostępująca fala demokratyzacji na świecie, nasilona szczególnie w drugiej połowie XX wieku, przyniosła zapotrzebowanie na wytworzenie narzędzi teoretycznych umożliwiających opisywanie, analizowanie i wyjaśnianie tego zjawiska. Podjęte zostały między innymi próby ilościowych analiz relacji między procesami demokratyzacji i stabilizacji systemów demokratycznych a innymi charakterystykami tych systemów, opisywania ich poprzez pryzmat całego szeregu ilościowych zmiennych odzwierciedlających ich specyfikę, a także integrowania tych zmiennych w syntetyczne wskaźniki. W połączeniu z gwałtownym rozwojem ilościowych metod w politologii porównawczej, a także tendencjami do ich formalizowania oraz poszerzania zakresu przedmiotowego analiz ${ }^{1}$, przyczyniło się to do wytworzenia specyficznych konstrukcji teoretyczno-metodologicznych, służących do całościowego charakteryzowania systemów politycznych pod względem stopnia ich demokratyczności. Tymi konstrukcjami są tzw. skale demokracji politycznej, niekiedy określane również jako indeksy demokracji bądź wskaźniki demokratyczności systemów politycznych (democracy indices). Są to syntetyczne narzędzia pomiaru, mające za zadanie przedstawienie zmiennej demokratyczności w postaci jednej wartości liczbowej, w odniesieniu do dowolnego systemu politycznego.

Skale demokracji politycznej są narzędziem często stosowanym w zachodniej, szczególnie anglosaskiej, politologii porównawczej. Zwykle używa się nie samych skal, ale konkretnych wyników pomiarów, przedstawionych przez Autorów skal w postaci tzw. zbiorów danych (datasets) o systemach politycznych. Każdy zbiór oparty jest na przygotowanej wcześniej metodologii pomiaru i interpretacji jego wyników. Składają się nań konkretne wartości liczbowe, mające odzwierciedlać poziom demokratyczności określonych systemów politycznych w wyznaczonych punktach bądź przedziałach czasowych. Zbiory danych stanowią bardzo poręczne, mające szerokie możliwości zastosowania oraz łatwo dostępne dla komparatystów politycznych źródło danych do prowadzonych analiz. Dziwić więc może, przynajmniej na pierwszy rzut oka, fakt, iż nie są one szeroko znane i wykorzystywane w polskiej politologii. Zadaniem niniejszego artykułu jest więc krótkie przybliżenie Czytelnikom problematyki budowy skal demokracji, a także naszkicowanie podstaw teoretycznych i metodologicznych na jakich to narzędzie badawcze jest oparte.
\end{abstract}

\footnotetext{
${ }^{1}$ Por. m.in. G. L. Munck, The Past and Present of Comparative Politics, w: G. L. Munck, R. Snyder, Passion, Craft, and Method in Comparative Politics, John Hopkins University Press, Baltimore (MD) 2007, s. 38-58.
} 
Pomiar demokracji jest niewątpliwie interesującym kierunkiem analiz, których wykorzystanie może przynosić szeroko zakreślone, dobrze ugruntowane i ciekawe wnioski badawcze, dlatego warto się zapoznać z jego podstawami. Należy jednak pamiętać, że jest to bardzo trudna procedura, której przeprowadzanie obciążone jest wieloma niedogodnościami natury badawczej. Stąd drugim zadaniem artykułu jest wskazanie na najważniejsze problemy metodologiczne, z jakimi borykać się musi badacz konstruujący skalę demokracji oraz wykorzystujący ją do stworzenia zbioru danych na ten temat. Możliwe jest to jedynie przy zachowaniu bardzo wygórowanych standardów metodologicznych i przeprowadzeniu odpowiedniej sekwencji kroków zmierzających w tym kierunku. W kolejnej części artykułu zaprezentowano zatem jak taki proces tworzenia skali demokracji powinien wyglądać. Na koniec wreszcie wskazano na kilka przykładów koncepcji powstałych w ramach polskiej politologii, obracających się wokół problemu pomiaru demokracji i demokratyzacji. Jakkolwiek nie mają one zamkniętej, sfinalizowanej formy, mogą dawać nadzieję, że ten kierunek badań politologicznych został dostrzeżony i będzie kontynuowany przez naszych rodzimych badaczy.

Nie da się ukryć, że jednym z motywów napisania niniejszego artykułu jest nadzieja wzmocnienia tego, na razie dość wątłego, trendu. Publikacja służyć ma zatem przede wszystkim popularyzacji wśród polskich politologów poręcznego narzędzia teoretyczno-metodologicznego, jakim są skale demokracji i zbiory danych o demokratyczności systemów politycznych na świecie. W ramach kontynuacji tego zadania, Autor planuje przedstawienie w następnym numerze czasopisma kilku najbardziej znanych i najszerzej stosowanych skal i zbiorów danych.

\section{Zastosowania skal demokracji politycznej}

Pomiar i ocena jakości demokracji mogą być prowadzone z różnych pobudek i służyć rozmaitym celom, między innymi w zależności od tego kto je prowadzi. Krąg podmiotów wykorzystujących zbiory danych oraz biorących udział $\mathrm{w}$ ich tworzeniu, jest bowiem bardzo szeroki i obejmuje między innymi agencje rządowe, organizacje międzynarodowe, organizacje pozarządowe (NGOs), badaczy pracujących na uniwersytetach, jak i w innych placówkach badawczych (na przykład w tzw. think tankach) i wiele innych. Wśród najważniejszych celów i zastosowań tego typu analiz należy wymienić:

— badanie relacji empirycznych między demokracją a różnymi zmiennymi charakteryzującymi systemy polityczne, ekonomiczne i społeczne;

— identyfikacja pozycji poszczególnych państw na tle pozostałych;

— tworzenie i monitorowanie projektów pomocy zagranicznej;

- kierowanie w odpowiednie miejsca inwestycji o charakterze ekonomicznym i społecznym;

— podnoszenie poziomu świadomości na temat demokracji i jej kondycji;

- wspieranie debaty publicznej;

— projektowanie reform demokratyzacyjnych i ocena ich efektów ${ }^{2}$.

Z politologicznego punktu widzenia istotny jest przede wszystkim pierwszy z wymienionych celów, w pewnym stopniu również drugi. Wszystkie pozostałe należą natomiast bardziej

${ }^{2}$ D. Beetham, E. Carvalho, T. Landman, S. Weir, Assessing the Quality of Democracy. A Practical Guide, Stockholm 2008, s. 306. 
do sfery praktyki społecznej, a nie analiz o charakterze naukowym. Jednak nawet tylko w tak wąsko zakrojonym obszarze badań mamy do czynienia z dużą ich różnorodnością, zarówno w zakresie ujęcia statycznego (badanie funkcjonowania demokracji), jak i dynamicznego (analiza procesów demokratyzacji i konsolidacji demokracji).

W sferze rozważań teoretycznych i empirycznych analiz porównawczych badania nad uwarunkowaniami demokratycznej stabilności i czynnikami sprzyjającymi bądź ograniczającymi demokratyzację mają status jednego z centralnych zagadnień politologii ${ }^{3}$. Analizy te, szczególnie rozpowszechnione w politologii anglosaskiej, polegają na poszukiwaniu korelacji pomiędzy różnego typu czynnikami, traktowanymi jako zmienne niezależne (na przykład: struktura i pochodzenie elit politycznych, typ wcześniejszego reżimu totalitarnego lub autorytarnego, zmienne podmiotowe typu wykształcenie czy kapitał społeczny w danym społeczeństwie itd.), a przebiegiem i rezultatami procesu demokratyzacji, które uznaje się wówczas za zmienną zależną ${ }^{4}$. Operacjonalizacja zmiennych niezależnych nie nastręcza przy tym zazwyczaj kłopotu, są one bowiem często zmiennymi prostymi i jednoznacznymi (np. poziom zamożności społeczeństwa mierzony skalą dochodu narodowego brutto per capita, poziom wykształcenia mierzony przez współczynnik scholaryzacji itp.), bądź panuje co do nich szeroka zgodność lub znajdują one swoje silne umocowanie teoretyczne (np. poziom rozwoju społecznego mierzony przez wysokość tzw. Human Development Index czy kapitał społeczny - w zależności od przyjętej jego koncepcji). Dużo trudniejszym zadaniem wydaje się być pomiar stopnia zaawansowania demokratyzacji i ocena rezultatów tego procesu, czyli określenie stopnia demokratyczności badanych systemów. I realizacji tego właśnie zadania służyć mają odpowiednie indeksy czy skale demokracji politycznej, na podstawie których tworzy się zbiory danych.

Szczególnie silne zapotrzebowanie na narzędzia teoretyczne analizy procesów demokratyzacji wiąże się z upadkiem tzw. obozu państw realnego socjalizmu i masową transformacją tych krajów w stronę reżimu demokratycznego. Z jednej bowiem strony na przestrzeni ostatnich lat mieliśmy do czynienia z ilościowym nasileniem zjawiska demokratyzacji ${ }^{5}$, z drugiej zaś również z jakościowo nowym, niespotykanym wcześniej charakterem przemian ${ }^{6}$. Wyrażał się on po pierwsze w szczególnie szerokim zakresie zmian społecznych, obejmujących nie tylko sferę polityki czy gospodarki, ale praktycznie wszystkie dziedziny życia społecznego. Po drugie, także w głębokości zachodzących zmian, sprowadzających się niekiedy do wytworzenia się całkowitego przeciwieństwa porządku obowiązującego w danej sferze wcześniej. Już po kilku latach transformacji postkomunistycznej zauważono również, że wbrew optymistycznym założeniom teorii modernizacji i konwergencji ${ }^{7}$ i oczekiwaniom niektórych autorów $^{8}$, przemiany te nie zawsze prowadzą do punktu wyznaczonego przez funkcjonujący

\footnotetext{
${ }^{3}$ D. Reiter, Does Peace Nurture Democracy?, „The Journal of Politics” 2001, vol. 63 Issue 3, s. 936.

${ }^{4}$ Patrz np.: A. Antoszewski, Współczesne teorie demokracji, w: Studia z teorii polityki, t. II, red. A. W. Jabłoński, L. Sobkowiak, Wrocław 1998, s. 17-23.

${ }^{5}$ Przykładowo według danych organizacji Freedom House w 1989 roku istniało na świecie 69 tzw. demokracji wyborczych, zaś w ciągu następnych dwudziestu lat liczba ta wzrosła do 119 (http://www.freedomhouse.org/uploads/fiw09/CompHistData/EDNumbers\&Percentages.pdf [5.01.2010]).

${ }^{6}$ Z. Blok, Transformacja jako konwersja funkcji wewnatrzsystemowych na przykładzie Polski, Poznań 2006, s. 133-136; Z. Blok, Transformacja - uniwersalny czy unikalny charakter doświadczeń, w: Modernizacja polityczna w teorii i praktyce. Filozoficzne aspekty i dziedziny modernizacji, red. M. Barański, Katowice 2009.

${ }^{7}$ Por. m.in. M. S. Szczepański, Teorie zmian spolecznych. Wybrane zagadnienia, cz. 1: Teorie modernizacji, Katowice 1985, s. 5-34; A. W. Jelonek, K. Tyszka, Koncepcje rozwoju społecznego, Warszawa 2001, s. 75-77 oraz 83-88.

${ }^{8}$ Patrz na przykład: F. Fukuyama, The End of History, ,The National Interest” Summer 1989; F. Fukuyama, Koniec historii, Poznań 1996.
} 
w krajach kręgu euroatlantyckiego model demokracji liberalnej. Często bowiem zmierzają one ku innym, bardziej ograniczonym modelom demokracji i semidemokratycznym formom rządów, i jest to nie tylko kwestia tempa przemian, ale ich punktu docelowego ${ }^{9}$. W tej sytuacji kluczowym zagadnieniem staje się zmierzenie tempa i dynamiki przemian demokratyzacyjnych, a także ich kierunku, poprzez zestawienie z modelem idealnym demokracji liberalnej, wyznaczającym szczytowy punkt skali demokracji.

Niektóre ze zbiorów danych umożliwiają także prowadzenie analiz o charakterze długofalowym, albowiem obejmują one wartości wskaźników w okresie rzędu dwóch wieków. Takie analizy stanowić mogą, jak się wydaje, zupełnie odrębne pole badawcze, łączące w sobie wątki politologiczne $\mathrm{z}$ historycznymi.

\section{Problemy metodologiczne tworzenia skal demokracji}

Jakkolwiek nie można zaprzeczyć użyteczności narzędzia teoretycznego, jakim są skale demokracji, to zauważyć trzeba, że ich twórcy zmagać się muszą z wieloma problemami natury teoretycznej i metodologicznej. Ujęcie tak złożonego zjawiska, jakim jest demokracja, w ramy jednego syntetycznego wskaźnika, i to najczęściej wyrażonego w postaci liczbowej, nie jest zadaniem ani łatwym, ani dającym się wykonać w sposób bezdyskusyjny.

Przedstawianie zjawisk społecznych oraz charakterystyk systemów politycznych w postaci skwantyfikowanej niemal zawsze wiąże się z pewnymi trudnościami natury metodologicznej i epistemologicznej. Skale demokracji nie są tu żadnym wyjątkiem. Wydaje się, że w przypadku pomiaru demokracji mamy dodatkowo do czynienia z zestawem czynników specyficznych, jeszcze bardziej utrudniających przeprowadzanie tego typu procedury badawczej. Są to między innymi:

- pluralizm teorii demokracji - istnieje wiele definicji i konceptualizacji tego pojęcia, spory toczą między sobą zwolennicy nieprzystających do siebie i niekiedy wręcz przeciwstawnych sposobów pojmowania demokracji, np. demokracji substancjalnej i proceduralnej, konsensualnej i agonistycznej itd. ${ }^{10}$;

— duży rozdźwięk między ustaleniami teoretycznymi a możliwościami operacjonalizacyjnymi - w przypadku pomiaru stopnia demokratyczności systemów trudno jest przejść od poziomu teoretycznego do operacyjnego (konkretnych zmiennych); jest to konsekwencją m.in. sposobu konstruowania teorii demokracji - o ile w przypadku wielu innych kategorii podstawą są badania empiryczne następnie dopiero uogólniane w ustalenia teoretyczne, to tu teoria wypływa głównie z założeń ontologicznych i aksjologii, a później dopiero zostaje zoperacjonalizowana dla potrzeb badań empirycznych;

— złożoność i wielowymiarowość demokracji - powoduje, że ujęcie owej niosącej w sobie tak wiele treści kategorii w ramy prostego wskaźnika liczbowego wiązać się zawsze musi z ogromnym uproszczeniem, redukcją złożoności i zubożeniem treściowym;

— zasadniczo jakościowy charakter wielu elementów składowych demokracji - jest on przyczyną tego, że trudno je przełożyć na wskaźniki liczbowe lub jakiekolwiek inne podlegające agregacji; zabieg kwantyfikowania zjawisk jakościowych jest zawsze

${ }^{9}$ T. Carothers, The End of the Transition Paradigm, ,Journal of Democracy” 2002, vol. 13, Issue 1.

${ }^{10} \mathrm{Na}$ temat wielości modeli i sposobów pojmowania demokracji patrz m.in.: L. Rajca, Demokracja. Studium polityczne, Toruń 2007, s. 10-73; W. Szewczak, Wspólczesne problemy demokracji (tekst nieopublikowany, w przygotowaniu do druku). 
dość ryzykowny pod względem metodologicznym, zazwyczaj niesie też za sobą dużą dozę subiektywności w ocenie ze strony badacza;

— aksjologiczne uwikłanie kategorii demokracji - powoduje, że badaczom niekiedy trudno jest oddzielić to co rzeczywiście należy zaliczać do istoty demokracji od innych pozytywnie wartościowanych zjawisk, często silnie z demokracją skorelowanych, niebędących jednakże składowymi tej kategorii ${ }^{11}$;

- konsekwencje praktyczne sposobu skonstruowania skali demokracji - jej kształt przesądzić może o tym czy dany kraj zostanie uznany za demokratyczny i w jakim stopniu, a zatem ma duże znaczenie dla ludzi żyjących w tym systemie, a przede wszystkim dla funkcjonującej w nim elity rządzącej. Ten problem dotyczyć może w szczególności badaczy z krajów przechodzących tranzycję, którzy mogą być narażeni na mniej lub bardziej świadome i wyraźne naciski ze strony władzy, własnego środowiska naukowego, na autocenzurę itp.;

— jednym z najważniejszych zagadnień, jakie są przedmiotem analizy ze strony badaczy procesów demokratyzacji jest stabilność porządku demokratycznego - w rezultacie proponowane wskaźniki odnoszą się niekiedy raczej do stabilności systemu demokratycznego i prawdopodobieństwa powrotu do rządów autokratycznych, aniżeli do oceny jakości samej demokracji czy stopnia zaawansowania procesów demokratyzacyjnych.

Wszystkie wymienione powyżej problemy sprawiają, że skonstruowanie jednoznacznej i nie budzącej kontrowersji skali demokracji jest zadaniem bardzo trudnym, a być może wręcz niewykonalnym. Czym niemniej wysiłki w tym kierunku są podejmowane, zbudowanych zostało do tej pory wiele narzędzi pomiaru poziomu demokratyczności systemów politycznych. Wątpliwości natury teoretycznej i metodologicznej ustępują zatem przed potencjalnymi korzyściami mogącymi płynąć z zastosowania dalece niedoskonałych nawet skal. Pomiar demokracji jest nieodzowny do badań porównawczych i zmierzających do wyjaśnienia fenomenu demokratyzacji, za jego dokonywaniem przemawiają również względy czysto praktyczne. Wyniki pomiaru są bowiem wykorzystywane przez rządy krajów demokratycznych i organizacje pozarządowe do monitorowania sytuacji w otoczeniu międzynarodowym, używa się ich do oceny poziomu i jakości demokracji w poszczególnych państwach, projektowania zmian demokratyzacyjnych, a także do promowania i umacniania tego ustroju na świecie.

\section{Konstruowanie i ocena jakości skali demokracji}

Wymienione wyżej czynniki powodują, że konstruowanie skali demokracji, aby dać zadowalające wyniki, musi się opierać na bardzo rygorystycznych standardach metodologicznych. Podstawowym wyzwaniem jest zapewnienie odpowiedniej rzetelności i trafności skali oraz ich oszacowanie. Aby uzyskać pożądany efekt, proces konstruowania skali demokracji musi opierać się na zastosowaniu zaawansowanych metodologicznie procedur oraz przebiegać przynajmniej w kilku etapach. Poniżej zostanie przedstawiony taki proces, odtworzony na podstawie analizy konstrukcji kilku najbardziej znanych skal demokracji, przeprowadzonej przez Gerardo L. Muncka i Jay’a Verkuilena. Wyróżnili oni trzy podstawowe etapy budowy

\footnotetext{
${ }^{11}$ P. C. Schmitter, T. L. Karl, What Democracy Is... and Is Not, ,Journal of Democracy” 1991, vol. 2, Issue 3, s. $85-87$.
} 
skali demokracji, odpowiadające trzem najważniejszym wyzwaniom, jakim muszą sprostać jej twórcy: wyzwanie konceptualizacji, pomiaru oraz agregacji ${ }^{12}$.

Pierwszym zadaniem w ramach procedury tworzenia skali demokracji jest jej konceptualizacja. Przesądza ona o jednym z podstawowych kryteriów jakości skali, a mianowicie o jej trafności ${ }^{13}$. Przede wszystkim chodzi tu o osadzenie tworzonego indeksu w odpowiedniej teorii demokracji, wyprowadzenie z niej zestawu atrybutów systemu politycznego wskazujących na jego demokratyczność oraz odpowiednią organizację logiczną tychże atrybutów. Ponieważ nie istnieje jedna powszechnie uznawana i wyłącznie poprawna definicja demokracji, to w pierwszym etapie badacz ma swobodę wyboru tego, na jakiej koncepcji chce się oprzeć. G. Munck i J. Verkuilen wskazująjedynie, że warto aby nie traktowała ona demokracji w zbyt szeroki lub zbyt wąski sposób. Można do tego dodać postulat by wybrana koncepcja dawała się względnie klarownie i jednoznacznie przekładać na takie zmienne operacyjne, które poddadzą się empirycznej obserwacji i procedurze pomiaru. W praktyce większość skal opiera się na koncepcji poliarchii Roberta Dahla, a zatem mierzą nie tyle demokratyczność, co raczej poliarchiczność systemów politycznych. Jest to jedna z konsekwencji faktu, że „poliarchia” jako kategoria analityczna de facto w ogóle wyparła „demokrację” w zachodnich empirycznych badaniach politologicznych ${ }^{14}$. W konsekwencji proponowane skale koncentrują się zazwyczaj na proceduralnych aspektach funkcjonowania systemu demokratycznego i ten wymiar uznają za decydujący. Twórcy wielu skal mają też problemy - w ocenie Muncka i Verkuilena - ze zbyt minimalistycznym traktowaniem demokracji.

Oprócz ustalenia katalogu istotnych atrybutów demokracji, na tym etapie twórcy skali muszą jeszcze przeanalizować sieć relacji zachodzących między nimi. Chodzi tu przede wszystkim o analizę relacji nadrzędności/podrzędności między poszczególnymi atrybutami oraz określenie stopnia abstrakcyjności atrybutów. Dzięki temu zabiegowi badacz może ograniczyć katalog zmiennych bezpośrednio poddawanych pomiarowi do tych, które są proste i jednowymiarowe, a także określić sposób ich zagregowania w zmienne złożone i abstrakcyjne kategorie teoretyczne. Równocześnie jednak musi on zadbać o to, by atrybuty z poszczególnych pięter „drzewka operacjonalizacyjnego" były na tym samym poziomie abstrakcji oraz by spełniały one warunek rozłączności. Nie jest to zadanie łatwe, albowiem w ramach systemów demokratycznych istnieje wiele wzajemnych i ścisłych powiązań. Wobec wielu skal można mieć pod tym względem zastrzeżenia.

Drugim wyzwaniem jest problem określenia obserwowalnych wskaźników odpowiadających przyjętym wcześniej atrybutom systemu demokratycznego. W tym miejscu pojawia się kilka istotnych problemów. Po pierwsze trudno jest znaleźć takie wskaźniki operacyjne, które mogłyby mieć zastosowanie do wielu różnorodnych systemów politycznych. Jest to szczególnie istotne w przypadku zbiorów danych obejmujących szeroki zakres historyczny

\footnotetext{
${ }^{12}$ G. L. Munck, J. Verkuilen, Conceptualizing and Measuring Democracy: Evaluating Alternative Indices, „Comparative Political Studies” 2002, vol. 35, No. 1, s. 7-27.

${ }^{13}$ Trafnością skali określamy jej adekwatność do mierzonej zmiennej: Skala jest trafna wtedy, gdy mierzy to, co ma mierzyć wg intencji jej konstruktora (G. Babiński, Pomiar w naukach społecznych. Problemy ogólne i zasady budowy skal, w: Badania empiryczne w socjologii. Wybór tekstów, opr. M. Malikowski, M. Niezgoda, Tyczyn 1997, s. 285). Sprowadza się to w gruncie rzeczy do trzech pytań: Czy skala mierzy rzeczywiście continuum tej zmiennej, która interesuje badacza? Czy wynik pomiaru odzwierciedla tylko to continuum, czy też jest w pewnej mierze efektem błędu nielosowego lub stałego? Czy skala mierzy i jest reprezentatywna dla całego continuum zmiennej? (ibidem).

${ }^{14}$ M. Coppedge, W. H. Reinicke, Measuring Polyarchy, „Studies in Comparative International Development” 1990, vol. 25, No. 1, s. 52.
} 
i przestrzenny. Po drugie zaś, przy doborze katalogu składników trzeba się kierować również dostępnością i wiarygodnością posiadanych danych, zwłaszcza tych o charakterze historycznym, odnoszących się do systemów sprzed kilku i więcej dekad. Wreszcie pojawia się problem wyboru poziomu pomiaru - czy ma to być poziom ilorazowy, porządkowy, a może tylko jakościowy.

Ten etap procesu konstruowania skali demokracji przesądza o jej rzetelności oraz o powtarzalności i odtwarzalności pomiaru, czyli charakterystykach świadczących o walorach metodologicznych skali ${ }^{15}$. Aby je uzyskać, twórcy indeksu powinni nie tylko wybrać odpowiednie wskaźniki, ale również w maksymalnie precyzyjny sposób określić źródła danych, sformułować instrukcje kodowe, scharakteryzować przebieg procesu kodowania itd.

Wreszcie ostatnim wyzwaniem jest zagregowanie uzyskanych wyników w syntetyczne wskaźniki, mierzące zmienne o charakterze abstrakcyjnym. Wydawać by się mogło, że wyznaczenie reguły agregacji jest rzeczą prostą, jednak od dobrej skali wymaga się by nie był to zabieg czysto mechaniczny. Agregowanie wyników pomiarów cząstkowych winno być ugruntowane w teorii, zaś wskaźniki znajdujące się na różnych poziomach abstrakcji powinny z siebie wynikać i łączyć się w jeden spójny wymiar. Przy wyborze reguły agregacji badacz winien się odwołać explicite do teorii określającej relacje między poszczególnymi atrybutami demokracji oraz dopasować sformułowaną regułę agregacji do tychże relacji. Nie może się przy tym zamykać na testowanie tej reguły na konkretnych, rzeczywistych danych. Skala demokracji nie powinna być bowiem osadzona wyłącznie w wybranej teorii demokracji, ale również odpowiadać istniejącym rzeczywiście zależnościom między różnymi atrybutami, stwierdzonym w wyniku analiz materiału empirycznego. Do takich analiz wykorzystuje się często zaawansowane narzędzia statystyczne, takie jak na przykład konfirmacyjna analiza czynnikowa czy matryce korelacji między poszczególnymi wymiarami demokracji ${ }^{16}$.

Do reguł agregowania danych należałoby jeszcze dodać - czego G. Munck i J. Verkuilen już nie czynią - reguły interpretowania uzyskanych wyników. Same wartości liczbowe, niewiele przecież mówią, tym bardziej że nie istnieje żadna naturalna wartość progowa pozwalająca precyzyjnie i jednoznacznie oddzielić systemy demokratyczne od niedemokratycznych. Reguły interpretacji muszą mieć swoje zakorzenienie w odpowiedniej teorii albo przynajmniej wynikać z wyrażonych explicite założeń. Z pewnością muszą one również korespondować z uzyskanymi wynikami, w ten sposób aby kraje ewidentnie niedemokratyczne nie mogły zostać zakwalifikowane do grupy systemów demokratycznych i na odwrót.

Wszystkie powyższe etapy zostały przedstawione bardzo ogólnie. Już jednak samo takie ujęcie pokazuje, że konstruowanie skali demokracji jest zadaniem wymagającym dużych kompetencji oraz pokaźnego wysiłku ze strony jej twórców.

\footnotetext{
${ }^{15}$ Przez rzetelność skali należy rozumieć powtarzalność wyników pomiaru przeprowadzonego na tym samym obiekcie, w tych samych warunkach za pomocą tego samego narzędzia: Skala jest rzetelna, kiedy daje te same rezultaty przy każdym zastosowaniu do tej samej próby (W. J. Goode, P. K. Hatt, Podstawowe problemy pomiaru, w: Metody badań socjologicznych, opr. S. Nowak, Warszawa 1965, s. 261). Odmianą rzetelności jest odtwarzalność pomiaru, która zakłada, że wynik uzyskany dzięki zastosowaniu skali jest niezależny od tego kto ów pomiar przeprowadzi (oczywiście przy założeniu, że dokona tego w sposób prawidłowy). Z kolei powtarzalność pomiaru zakłada, że ta sama osoba wielokrotnie dokonująca pomiaru tego samego zjawiska przy pomocy tej samej procedury i skali będzie zawsze uzyskiwała taki sam wynik.

${ }^{16}$ Por. np. K. A. Bollen, Issues in the Comparative Measurement of Political Democracy, ,American Sociological Review" 1980, vol. 45, s. 377-379; A. Hadenius, Democracy And Development, Cambridge University Press, Cambridge-New York-Melbourne 1992, s. 61 oraz 70-71.
} 


\section{Problematyka pomiaru demokracji w politologii polskiej}

Wydaje się, że w polskiej politologii problematyka pomiaru demokracji nie znalazła dotąd tak poczesnego miejsca jak w anglosaskiej political science. Nie została dotąd stworzona całościowa koncepcja pomiaru demokracji, gotowa do zastosowania skala z jasno wyszczególnionymi wskaźnikami operacyjnymi, instrukcjami kodowymi, procedurami agregowania danych cząstkowych itd. Jest to prawdopodobnie konsekwencją faktu, iż ilościowe badania porównawcze $\mathrm{w}$ politologii polskiej nie są szeroko rozpowszechnione $-\mathrm{w}$ gruncie rzeczy szeroko zakrojone i systematyczne badania prowadzone są tylko przez badaczy z ośrodka wrocławskiego, przede wszystkim Andrzeja Antoszewskiego i Ryszarda Herbuta ${ }^{17}$. Samym problemem całościowego pomiaru demokracji jednak oni się nie zajęli, koncentrując się na analizach poszczególnych aspektów i części składowych systemów politycznych $\mathrm{z}$ osobna.

Niewątpliwie stworzenie skali pomiaru demokracji i opartego na niej zbioru danych jest zadaniem bardzo pracochłonnym. Problematyka ta wymaga poświęcenia jej wielu wysiłków i długotrwałych zabiegów badawczych oraz mocnej specjalizacji badawczej, która u nas - jak się wydaje - jeszcze się aż tak bardzo nie rozwinęła. Podobnie, nie jest aż tak mocno rozwinięta jak na Zachodzie, współpraca naszych badaczy z instytucjami rządowymi i pozarządowymi, wspierającymi demokratyzację i promującymi wartości demokratyczne (co wynika również ze słabszego rozwoju i mniejszej ilości takich instytucji i stowarzyszeń). Nie ma więc tak silnego zapotrzebowania na pomiar demokracji dla celów praktycznych, pozabadawczych.

Inną kwestią jest to, iż problematyka pomiaru demokracji wymaga od badacza nie tylko szerokiego rozeznania w teorii demokracji, ale przede wszystkim wysokich i dość specyficznych kompetencji metodologicznych. Nie przypadkowo ten kierunek badań rozwinięty jest przede wszystkim w politologii anglosaskiej, a zwłaszcza amerykańskiej. Amerykańskie nauki społeczne są bowiem oparte przede wszystkim o model badań ilościowych, dających wiarygodne, sprawdzalne i rzetelne wyniki, kosztem jednak powierzchowności uzyskanych rezultatów, niedostrzegania wszystkich niuansów i pełnej złożoności badanej rzeczywistości. W humanistyce i naukach społecznych Europy kontynentalnej przez długi czas dominował zaś (i nadal chyba dominuje, choć już w mniejszym stopniu) model przeciwstawny ${ }^{18}$. Wydaje się to być szczególnie widoczne w politologii polskiej, być może jest to w pewnej części pozostałość po poprzednim systemie. Po pierwsze bowiem obowiązujący wówczas paradygmat zwulgaryzowanego marksizmu w zasadzie nie dopuszczał ilościowych analiz porównawczych w badaniach nad systemami politycznymi. Po drugie natomiast, rzetelne porównywanie demokratyczności krajów zachodnich i systemów tzw. „demokracji ludowej” było ze względów ideologicznych niedopuszczalne, a gdyby nawet było możliwe, to i tak, wobec jakościowych różnic między nimi, byłoby pozbawione sensu.

$\mathrm{Na}$ te czynniki nakładają się zupełnie prozaiczne przyczyny, takie jak chociażby dostępność danych do porównań. Badacze prowadzący analizy poziomu demokratyczności systemów politycznych korzystają zazwyczaj z gotowych źródeł danych, takich jak na przykład The Stateman's Yearbook: Statistical and Historical Annual of the States of the World czy The

${ }^{17}$ Patrz m.in.: Systemy polityczne demokracji zachodnioeuropejskich. Wstęp do analizy porównawczej, red. A. Antoszewski, R. Herbut, Wrocław 1992; Demokracje zachodnioeuropejskie. Analiza porównawcza, red. A. Antoszewski, R. Herbut, Wrocław 1997; A. Antoszewski, R. Herbut, Systemy polityczne współczesnego świata, Gdańsk 2001; A. Antoszewski, R. Herbut, Systemy polityczne wspótczesnej Europy, Warszawa 2006.

18 Por. R. K. Merton, Teoria socjologiczna i struktura spoteczna, Warszawa 2002, s. 476-491. 
Europa World Year Book. Dokładna, dogłębna i wszechstronna analiza każdego kraju rok po roku byłaby ze względów technicznych niewykonalna lub bardzo kosztowna. Tymczasem na naszym rynku wydawniczym przez długi czas po prostu nie było takich cyklicznych opracowań dotyczących systemów politycznych wszystkich lub prawie wszystkich krajów świata, które byłyby przekrojowe, syntetyczne, ale i wyczerpujące.

W polskiej nauce pojawiło się jednak dotychczas kilka propozycji teoretycznych dotyczących pomiaru demokracji. Przykładowo Jerzy Wiatr w swoich rozważaniach na temat konsolidacji systemów demokratycznych stwierdza, iż dotychczas postulowane konstrukcje teoretyczne są zbyt wąskie i postuluje by w ocenie konsolidacji demokracji brać pod uwagę również jakość demokratycznych instytucji i sposobów postępowania. Jego zdaniem w takiej ocenie powinno się brać pod uwagę sześć kryteriów, które można traktować jako zmienne mierzące stopień demokratyczności systemu:

1) pokój wewnętrzny w państwie - czy wszystkie znaczące siły polityczne i odłamy społeczeństwa wyrzekają się przemocy jako sposobu realizacji interesów, uznając pokojowe i zgodne z prawem metody za wyłączne formy rozstrzygania konfliktów;

2) przestrzeganie przez wszystkie organy państwa ładu konstytucyjnego - czy w procesie rządzenia nie jest naruszany podział władz oraz inne normy konstytucyjne;

3) respektowanie przez państwo praw człowieka i obywatela - chodzi tu przede wszystkim o prawa odnoszące się do sfery politycznej (np. wolność słowa i zrzeszania się), mające zapewnić, że demokracja to nie tylko rządy większości, ale również poszanowanie praw mniejszości politycznych;

4) respektowanie praw mniejszości narodowych i religijnych - co ma im zapewnić swobodę rozwoju i udziału w życiu publicznym;

5) regularne i zgodne z konstytucyjnie wyznaczonymi terminami wybory parlamentarne oraz na inne przewidziane $\mathrm{w}$ konstytucji stanowiska pochodzące $\mathrm{z}$ wyboru;

6) niezależność sądów, respektowana przez władzę wykonawczą i ustawodawczą ${ }^{19}$.

Z kolei Zbigniew Blok poddaje krytyce istniejące dotychczas propozycje, stwierdzając że ilość funkcjonujących teorii, koncepcji i modeli demokracji praktycznie uniemożliwia stworzenie jednorodnego narzędzia jej pomiaru, a nawet zbudowanie jednolitej teorii demokratyzacji. W tej sytuacji, zdaniem Z. Bloka, wysiłki badaczy winny skoncentrować się raczej na opisie procesów demokratyzacyjnych, a nie na próbach tworzenia teoretycznych uogólnień czy mierzenia postępów demokratyzacji, idącej w różnych krajach w odmiennych kierunkach. Skoro bowiem przez wiele wieków nie udało się tak naprawdę zdefiniować w zadowalający sposób demokracji, to i poszukiwania jednego, nie pozostawiającego wątpliwości katalogu kryteriów jej oceny jest zadaniem skazanym na niepowodzenie ${ }^{20}$. Pojawiły się także postulaty by w pomiarze demokratyczności systemów politycznych oraz przede wszystkim postępów ich demokratyzacji w większym niż dotąd stopniu uwzględniać lokalną specyfikę tych systemów oraz kontekstu kulturowego i historycznego w jakim procesy demokratyzacji zachodzą. Uwzględnienie specyfiki typu zmiany społecznej, jakim jest transformacja systemowa, mogłoby bowiem dać bardziej miarodajne wyniki, odnoszone do bardziej jednolitej klasy badanych przedmiotów, jakimi są państwa tą transformację przechodzące ${ }^{21}$.

\footnotetext{
19 J. J. Wiatr, Socjologia wielkiej przemiany, Warszawa 1999, s. 121-123.

${ }^{20}$ Z. Blok, Krytyczna refleksja nad wybranymi teoriami i kryteriami ocen demokratyzacji, w: Polska i Europa Środkowa. Demokratyzacja, konsolidacja, europeizacja, red. E. Nowak, R. Riedel, Lublin 2010 (w druku).

${ }^{21}$ W. Szewczak, Pomiar postęów demokratyzacji w krajach przechodzacych transformację systemowa, w: Polska i Europa Środkowa. Demokratyzacja, konsolidacja, europeizacja, red. E. Nowak, R. Riedel, Lublin 2010 (w druku).
} 
Propozycje polskich autorów mają jednak charakter jedynie szkiców teoretycznych, zarysowujących ogólną koncepcję pomiaru czy model na jakim powinien ów pomiar zostać oparty. Pełna skala, ze szczegółowo scharakteryzowanymi wskaźnikami operacjonalizacyjnymi, sposobami ich agregacji i interpretacji, przeprowadzonymi testami rzetelności i trafności pomiaru itd., w politologii polskiej jeszcze nie powstała. Jest to wprawdzie zadanie trudne i pracochłonne, ale wypada mieć nadzieję, że prędzej czy później któryś z rodzimych badaczy lub zespołów badawczych się go podejmie i zdoła sfinalizować z sukcesem. Mimo bogactwa propozycji w politologii zachodniej, można bowiem mieć poczucie pewnego niedosytu, związanego przede wszystkim z nadmierną powierzchownością uzyskiwanych rezultatów badawczych. Jest to przede wszystkim skutkiem dotychczasowego koncentrowania się na instytucjonalnych aspektach funkcjonowania demokracji. Możliwe zatem, że pewne wzbogacenie analiz mogłoby zostać wywołane dzięki faktowi, że nasi rodzimi badacze nie są aż tak silnie zorientowani na ujmowanie demokracji w kategoriach wyłącznie instytucji i procedur. Już samo to, że nie jesteśmy tak mocno „uwiązani” dominującą na Zachodzie koncepcją poliarchii, mogłoby wprowadzić pewne elementy świeżości w analizach.

\section{Zakończenie}

Dokonywanie ilościowego pomiaru zjawisk politycznych, za wyjątkiem tych, które mają ze swojej natury ilościowy charakter (np. frekwencja wyborcza), zawsze jest kontrowersyjnym, z metodologicznego punktu widzenia, zabiegiem badawczym. W przypadku prób ilościowego przedstawienia poziomu demokracji mamy dodatkowo do czynienia $\mathrm{z}$ bardzo dużym stopniem złożoności badanego zjawiska, która zawsze w procesie pomiaru musi zostać radykalnie zredukowana. Bogate i różnorodne relacje i powiązania między różnymi elementami systemu demokratycznego muszą zostać pominięte lub co najwyżej sprowadzone do „suchych” wartości liczbowych. Różne, stanowiące odrębne całości, ale i wchodzące ze sobą w zależności i interakcje, wymiary składające się na badane zjawisko, zostają w nienaturalny sposób połączone, zintegrowane w ramach jednej zmiennej ${ }^{22}$. Można by zadać pytanie: skoro tak jest, to dlaczego tak karkołomne zadanie, jakim jest pomiar demokracji, jest w ogóle podejmowane?

Odpowiedzią wydaje się być pragmatyka badawcza. Wprawdzie nie jesteśmy w stanie stworzyć doskonałego czy choćby w jakiś sposób do doskonałości się zbliżającego narzędzia pomiaru demokracji, to korzyści z niedoskonałego nawet pomiaru mogą przeważać nad stratami wynikającymi z jego niedokładności. Pomiar demokracji otwiera bowiem wiele nowych pól badawczych oraz możliwości dokonywania analiz porównawczych, bardzo istotnych z punktu widzenia badawczego, jak i praktycznego. Najwyraźniej z takiego założenia wychodzi bardzo wielu badaczy, jak bowiem policzył Russel L. Barsh, tylko w latach 1954-1965

\footnotetext{
${ }^{22}$ Między innymi dlatego pojawiają się propozycje zdezagregowanego pomiaru demokracji, w którym ów wątpliwy metodologicznie zabieg zostaje ominięty. Por. m.in. M. Coppedge, J. Gerring, Measuring Democracy: A Multidimensional, Tiered, And Historical Approach (proposal), Boston-Notre Dame 2009, dostępny w wersji elektronicznej: http://people.bu.edu/jgerring/documents/MeasuringDemocracy.pdf [22.05.2010]; J. Gerring, Measuring Democracy: Proposal for a Disaggregated Approach, prezentowany na APSA 2008 Annual Meeting, Hynes Convention Center - Boston (MA), 28 sierpnia 2008, dostępny on-line: http://www.allacademic.com/meta/p280410_index.html [6.06.2010].
} 
powstało ponad 2000 skal pomiaru demokracji ${ }^{23}$. Jest to więc trudne i ambitne zadanie, jednak mogące przyczyniać się do bardzo ważnych dla rozwoju politologii ustaleń badawczych.

$\mathrm{Z}$ zadaniem tym badacze próbują radzić sobie w różny sposób, czasem z lepszym, a czasem z gorszym efektem. W chwili obecnej można wyodrębnić kilka, może kilkanaście takich skal, które są szczególnie dobrze znane i często przytaczane oraz wykorzystywane w politologicznych analizach porównawczych. Ich charakterystyka oraz analiza tego, w jaki sposób podchodzą one do skomplikowanego zagadnienia pomiaru demokracji, będzie przedmiotem kolejnego artykułu.

\section{Bibliografia}

Antoszewski A., Herbut R. (red.), Demokracje zachodnioeuropejskie. Analiza porównawcza, Wrocław 1992.

Antoszewski A., Herbut R. (red.), Systemy polityczne demokracji zachodnioeuropejskich. Wstęp do analizy porównawczej, Wrocław 1992.

Antoszewski A., Herbut R., Systemy polityczne wspótczesnego świata, Gdańsk 2001.

Antoszewski A., Herbut R., Systemy polityczne współczesnej Europy, Warszawa 2006.

Antoszewski A., Wspótczesne teorie demokracji, w: Studia z teorii polityki, t. II, red. A. W. Jabłoński, L. Sobkowiak, Wrocław 1998.

Babiński G., Pomiar w naukach społecznych. Problemy ogólne i zasady budowy skal, w: Badania empiryczne w socjologii. Wybór tekstów, opr. M. Malikowski, M. Niezgoda, Tyczyn 1997.

Beetham D., Carvalho E., Landman T., Weir S., Assessing the Quality of Democracy. A Practical Guide, Stockholm 2008.

Blok Z., Krytyczna refleksja nad wybranymi teoriami i kryteriami ocen demokratyzacji, w: Polska i Europa Środkowa. Demokratyzacja, konsolidacja, europeizacja, red. E. Nowak, R. Riedel, Lublin 2010 (w druku).

Blok Z., Transformacja - uniwersalny czy unikalny charakter doświadczeń, w: Modernizacja polityczna $w$ teorii i praktyce. Filozoficzne aspekty i dziedziny modernizacji, red. M. Barański, Katowice 2009.

Blok Z., Transformacja jako konwersja funkcji wewnątrzsystemowych na przykładzie Polski, Poznań 2006.

Bollen K. A., Issues in the Comparative Measurement of Political Democracy, „American Sociological Review" 1980, vol. 45.

Carothers T., The End of the Transition Paradigm, „Journal of Democracy” 2002, vol. 13, Issue 1.

Coppedge M., Gerring J., Measuring Democracy: A Multidimensional, Tiered, And Historical Approach (proposal), Boston-Notre Dame 2009 (wersja elektroniczna: http://people.bu.edu/jgerring/documents/MeasuringDemocracy.pdf [22.05.2010]).

Coppedge M., Reinicke W. H., Measuring Polyarchy, „Studies in Comparative International Development” 1990, vol. 25, No. 1.

Fukuyama F., Koniec historii, Poznań 1996.

Fukuyama F., The End of History, „The National Interest”, Summer 1989.

Gerring J., Measuring Democracy: Proposal for a Disaggregated Approach, referat prezentowany na APSA 2008 Annual Meeting, Hynes Convention Center - Boston (MA), 28 sierpnia 2008, (wersja elektroniczna: http://www.allacademic.com/meta/p280410_index.html [06.06.2010]).

Goode W. J., Hatt P. K., Podstawowe problemy pomiaru, w: Metody badań socjologicznych, opr. S. Nowak, Warszawa 1965.

Hadenius A., Democracy And Development, Cambridge University Press, Cambridge-New York-Melbourne 1992.

${ }^{23}$ R. L. Barsh, Measuring Human Rights. Problems of Methodology and Purpose, „Human Rights Quarterly” 1993, vol. 15 No. 1, s. 91; za: T. Landman, J. Häusermann, Map-Making and Analysis of the Main International Initiatives on Developing Indicators on Democracy and Good Governance, University of Essex - Human Rights Centre, Report for the Statistical Office of the Commission of the European Communities (Eurostat), Colchester-Ipswich 2003, s. 8. 
Jelonek A. W., Tyszka K., Koncepcje rozwoju społecznego, Warszawa 2001.

Landman T., Häusermann J., Map-Making and Analysis of the Main International Initiatives on Developing Indicators on Democracy and Good Governance, University of Essex - Human Rights Centre, Report for the Statistical Office of the Commission of the European Communities (Eurostat), Colchester-Ipswich 2003.

Merton R. K., Teoria socjologiczna i struktura spoleczna, Warszawa 2002.

Munck G. L., Verkuilen J., Conceptualizing and Measuring Democracy: Evaluating Alternative Indices, „Comparative Political Studies” 2002, vol. 35, No. 1.

Munck G. L., The Past and Present of Comparative Politics, w: G. L. Munck, R. Snyder, Passion, Craft, and Method in Comparative Politics, John Hopkins University Press, Baltimore (MD) 2007.

R. L. Barsh, Measuring Human Rights. Problems of Methodology and Purpose, „Human Rights Quarterly” 1993, vol. 15 , No. 1.

Rajca L., Demokracja. Studium polityczne, Toruń 2007.

Reiter D., Does Peace Nurture Democracy?, „The Journal of Politics” 2001, vol. 63, Issue 3.

Schmitter P. C., Karl T. L., What Democracy Is... and Is Not, „Journal of Democracy” 1991, vol. 2, Issue 3.

Szczepański M. S., Teorie zmian społecznych. Wybrane zagadnienia, cz. 1: Teorie modernizacji, Katowice 1985

Szewczak W., Pomiar postęów demokratyzacji w krajach przechodzqcych transformację systemowq, w: Polska i Europa Środkowa. Demokratyzacja, konsolidacja, europeizacja, red. E. Nowak, R. Riedel, Lublin 2010 (w druku).

Szewczak W., Wspótczesne problemy demokracji (tekst nieopublikowany).

Wiatr J. J., Socjologia wielkiej przemiany, Warszawa 1999.

[Freedom House], Freedom in the World - Electoral Democracies, http://www.freedomhouse.org/uploads/fiw09/CompHistData/EDNumbers\&Percentages.pdf [5.01.2010].

\section{Summary}

The author of the paper undertakes to present and analyze one of the research instruments applied by comparative political science in quantitative surveys, namely scales of democracy (sometimes referred to as indices or factors of democracy). This instrument is quite common in Western, in particular Anglo-Saxon political science, whereas it remains relatively unknown in Polish political science. The aim of the paper is therefore to introduce the reader to this theoretical and methodological construct.

In order to achieve this aim the author indicates the possible uses of scales of democracy and the areas of research that apply them. He also analyzes methodological problems related to the development and application of scales of democracy. Although they offer a useful tool in comparative analyses, the essence of this instrument may raise certain methodological and epistemological doubts. Therefore it is significant to maintain the utmost diligence when developing these scales, which must be based on the application of advanced statistical instruments and research algorithms. On the basis of the conclusions of G. L. Munck and J. Verkuilen, the author presents a model process for developing scales of democracy and demonstrates the challenges faced by the researcher trying to develop such scales. The last part of the paper discusses the place of the issue of democracy measurement in Polish political science. The author claims that Polish researchers' interest in this issue does not correspond to its significance and the potential advantages that could be obtained. 